\title{
An analysis of underlying factors for implementing privatization in Irani- an sport
}

\author{
Seyed Mohammad Hossein Razavi ${ }^{1}$, Amin Amani ${ }^{2}$ and Alireza Ghanbari Firouzabadi ${ }^{3}$ \\ 1 Associate Professor, Department of Sport Management, Faculty of Sport Science, University of Mazandaran, Babolsar, Iran. \\ 2 Ph.D Student of Sport Management, University of Shomal, Amol, Iran. E-mail: amani.amin.311@yahoo.com \\ 3 Assistant Professor, Department of Physical Education and Sport Sciences, University of Bojnoord, Bojnoord, Iran.
}

\begin{abstract}
The purpose of this research was to analyze the underlying factors of privatization implementation in Iran's sport, which was developed by developmental approach. Statistical population of this research was consisted of all managers and experts involved in sports privatization in the country. Regarding that this is a qualitative research, a total of 20 people were selected using the snowball purposeful sampling technique as a statistical sample. The data collection tool was interview. Interviews continued until the theoretical saturation stage was fulfilled. The data obtained from interviews were analyzed in three stages of open, axial and selective coding. The results of the research identified 41 concepts and 5 categories including factors related to financial market, management factors, media factors, cultural factors and legal factors that provide the platform for implementation of privatization in the sport of the country. According to the results of this research, privatization in Iran's sport has been affected by various conditions, it is suggested that sport authorities are encouraged to provide a condition in which people can be trained in order to gain specialty to enter in various areas such as advertising private sector and proper culture creation in press and TV and paying attention to philosophy of sport and culture creation among the people.
\end{abstract}

Keywords: Underlying Factors, Privatization, Sports, Sports Privatization, Data-based.

\section{INTRODUCTION}

Privatization is the process of transferring business ownership from the public sector (government) to the private sector. In a general sense, privatization refers to the transfer of any duty or function of the governmental tasks such as earning income and law enforcement (CHOWDHURY, 2006). Privatization is a means to improve productivity and increase efficiency at the level of the economy of a country, which ultimately leads to economic growth (MUNARI et al., 2002). Privatization refers to a range of acts which include asset sales, bidding, domestic sales, public-private partnerships, and liberalization (BATCH, 2000).
The sport privatization in the western and developed countries is very important and has been seriously addressed. One of the most important reasons is the economic importance of healthy sports and recreation (SMITH, 1997). In Latin America, as well as in Eastern European countries, despite the enormous attempts for privatization, the shadow of 52 years of socialist regimes and lack of proper financial infrastructure and the limitation of facilities has made these countries fail in this area. On the other hand, the lack of entrepreneurship and the weakness of the entrepreneurial class are other factors that make it difficult to achieve domestic and foreign capital. In developing countries, especially in Arab coun- 
tries, the capitalist class is often home to large families who seek easy and large profits and avoid business risks; therefore, as far as possible, they avoid investing in industrial units (AYUBI, 1996).

The experience of the studied countries suggests that if privatization is not carried out after comprehensive studies based on precise planning, if the necessary premises for its implementation are not provided and if its process is not monitored during and after its implementation, it will increase the injustice which will result in general dissatisfaction (GRUSKY, 2004). In the last decade, US sports have grown by 50 percent, and the value of this industry has been estimated at $\$ 400$ billion, which has led the industry to become one of the top ten industries (AYIM, 2009). The share of sport in the national economy has a direct and positive relationship with the amount of investment in the sports sector (CLARK et al., 2008).

Thanos and Kriemadis (2007) in their research entitled "Strategic marketing planning in the sports sector", in analyzing the marketing environment of sports organizations has explained the objectives of environmental analysis and has identified that the strengths of sports organizations are quality of service, technical and managerial skills, and innovation. Wu Xiao \& Hu, Xiao (2007) stated that China's economic development has attracted domestic and foreign investment followed by increase in popular support which ultimately leads to the development of the private sector. Also, private sector investment is comprehensive needs, which in the long run largely resists all economic structures and improve the function of the economic system, and this kind of investment is the objective need of the economy market. In a situation where private investment is inadequate, cooperation of government and the private sector in building sports venues is the only solution. At present, the collaboration of the government and the private sector in the construction of sports venues has increased dramatically, but the private sector has not yet found its place.

Amani et al. (2014) reviewed the management problems of privatized athletic facilities in northern Khorasan and Razavi Khorasan province. They found that the most important weaknesses in the statistical population is the lack of privatization methods in sports facilities, inappropriate supervision by state sector in the construction of sports facilities and increased maintenance cost after the transfer to the private sector, the small number of research in this area. The most important threats are the transfer of state-run sports facilities to the private sector regardless of the experience and expertise of individuals participating in bids at the highest price and political instability. In the process of privatization, the positive and negative environmental factors are always influential on its process. Identification and analysis of these factors affect the overall policies of the country and affect the performance of governmental and nongovernmental organizations. Among these, there are some positive factors such as good quality of services, technical and managerial skills, innovation (THANOS; KRIEMADIS, 2007), better maintenance of sporting facilities by the private sector (WU XIAO, 2007). there are also negative factors such as: failure to formulate a strategy for development Sports Facilities (SGL ADVISORY GROUP, 2006) and failure in providing appropriate opportunities such as the growing popular acceptance 
of sport, the potential for private sector investment in sport (WU XIAO, 2007). Some preventive factors include political instability (MIAO CHANG, 2008) and the Economic Downturn (KARLIS, 2007).

The main reason for developing privatization is to increase the efficiency of the economy and reduce the government's fiscal deficit. Because of its high technological skills, the private sector plays an important role in the production of more and more new products and services. The pursuit of profit and competition is one of the main elements of the private sector management. The studies show that the amount of investments made by the private sector in our country's sport is very small. In Iran, privatization was practically introduced in 1989, and the government sought to transfer the ownership of some of the government's economic activities to private sectors. This was followed by the Fourth Development Planning Act, and now it has been emphasized on implementation of Article 44 of the Constitution to attract public participation in order to carry out some of the tasks that the government is responsible for.

In this regard, privatization has been considered as an important issue in implementing Article 44 of the Constitution and continuing economic, social and cultural developmental programs. So that in the goals set by the economic transformation a plan, the transfer of public activities to the private sector is seriously in progress. As a sport infrastructure of the country, Privatization of sports venues has a special place. Accordingly, considering that the existing sports facilities and infrastructure do not meet the needs of the community and the current financial resources do not suffice to create the sport national movement of the country, attention to the participation and investment of the private sector is very necessary. In Iran, popular support and private sector investment are considered important as sport financial resource and since the government's resources are not enough to create employment opportunities and employment, private sector participation is essential to provide a good investment. Therefore, the present study, with a focus on privatization, aims at understanding the underlying factors affecting privatization implementation in Iranian sport. The results of this research will give the planners the idea to overcome the weaknesses they face. As a result, the incentives for the private sector and the proper platform for their presence have been created and the community and the government will benefit from it.

\section{METHODS}

This research seeks to analyze the underlying factors of the implementation of privatization in Iran's sport based on the views of the elite and professors of the universities. This research leads to an increase in existing knowledge about the subject. Therefore it is a developmental research and because the results of the research are applied in strategic management, so it is also an applied research. Since this research was to do a new and qualitative work, the data based method and qualitative analysis was used to achieve the research objectives.

In the field of research literature, all upper hand documents were part of the research statistical population. In the strategic domain, all managers and experts involved 
in sports privatization in the country were the statistical population. Regarding that this is a qualitative research, a total of 20 people were selected using the snowball purposeful sampling technique as a statistical sample. One of the reasons for using this sampling method is that all subjects have a certain occupation, skill or knowledge, and their number is negligible (HOOMAN, 2007). The point to be noted is that, in a qualitative study, the size of the sample does not increase the validity, and it can even reduce the accuracy and richness of the sample population; because the opportunity and the accuracy of examining a large sample is less than the small sample (ZOLFAGHARIYAN; LATIFI, 2011). In this study, to obtain the reliability, the agreements between the two encoders, based on Kappa coefficient were used. The kappa coefficient was 0.736 , which implies the assumption of the independence of the extracted codes is rejected and their inter dependence is confirmed. Therefore, it can be claimed that the coding has had sufficient reliability. To collect the data and answers to the questions, first, according to the characteristics specified in the statistical population and in consultation with advisor and supervisor professors, experts were identified and then they were interviewed. The interviews were conducted in full number and continued until the theoretical saturation was fulfilled. At the interview stage, when the 17th person was interviewed, the answers were duplicated and the researcher reached a theoretical saturation. However, in order to maintain diversity in the views of the interviewees, 20 people were interviewed but no significant change was obtained in the results of the data. So the interviews stopped. The method used in interviews was open and semi-open. For qualitative analysis of interviews by grounded theory, after collecting the data the files extracted from the interview were examined and different stages of analysis were conducted to answer the questions.

As mentioned earlier, this research has no hypothesis, and the main purpose of this analytical research is to analyze the underlying factors of implementation of privatization in Iran's sport with a qualitative approach. According to the research approach, each interview was provided in separate files. Their common features were identified by phased investigation in the form of concepts, categories, and theorems.

\section{FINDINGS}

Qualitative approach has been used in this research. In this study, 20 experts were interviewed. The interview began with questions about the proper context for the implementation of privatization in the country, and the remaining questions were asked according to the interviewee's answers. All interviews were recorded and analyzed and then they were used in the study.

Table 1 - The demographic characteristics of interviewees
\begin{tabular}{|c|l|c|c|}
\hline Variable & Demographic characteristics & $\begin{array}{c}\text { Frequen- } \\
\text { cy }\end{array}$ & $\begin{array}{c}\text { Frequency } \\
\text { percentage }\end{array}$ \\
\hline \multirow{3}{*}{ Sex } & Female & 3 & 0.15 \\
\cline { 2 - 4 } & male & 17 & 0.85 \\
\hline Education & MSc & 1 & 0.05 \\
\cline { 2 - 4 } & Ph.D. student & 2 & 0.10 \\
\cline { 2 - 4 } & PhD & 17 & 0.85 \\
\hline \multirow{5}{*}{ Workplace } & Ministry of Sport and Youth & 4 & 0.20 \\
\cline { 2 - 4 } & Ministry of Education & 2 & 0.10 \\
\cline { 2 - 4 } & Universities and Higher & 13 & 0.65 \\
\cline { 2 - 4 } & Education Centers & & \\
\cline { 2 - 4 } & Parliament Research Center & 1 & 0.05 \\
\hline \multirow{2}{*}{$\begin{array}{c}\text { Field of } \\
\text { Study }\end{array}$} & Physical Education & 1 & 0.05 \\
\cline { 2 - 4 } & Non-physical Education & 19 & 0.95 \\
\hline
\end{tabular}


As shown in Table (1), most of the samples were male, all had a research or executive background related to the subject, and was faculty members of universities or higher education institutions, and most interviewees had a doctoral degree in Physical Education.

In this research, it was tried to reach to a proper understanding of the appropriate context for the implementation of privatization in Iran's sport by discovering concepts and to answer the research questions in relation to the effective field of implementation of privatization in sport;

Table 2 - First level coding results

\begin{tabular}{|c|c|c|c|}
\hline Row & $\begin{array}{l}\text { Axial } \\
\text { code }\end{array}$ & Open code & Frequency \\
\hline 1 & \multirow{16}{*}{ 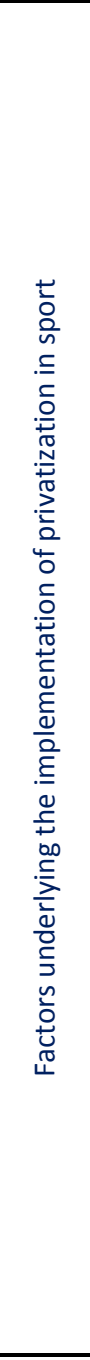 } & $\begin{array}{l}\text { The contribution of sports in the } \\
\text { national economy }\end{array}$ & 4 \\
\hline 2 & & $\begin{array}{l}\text { Sports industry turnover com- } \\
\text { pared to other industries }\end{array}$ & 2 \\
\hline 3 & & High interest rates in sport & 2 \\
\hline 4 & & \begin{tabular}{|l|l|}
$\begin{array}{l}\text { Training Specialized staff for } \\
\text { private sector to enter }\end{array}$ & \\
\end{tabular} & 11 \\
\hline 5 & & $\begin{array}{l}\text { Creating an investment market } \\
\text { for the private sector }\end{array}$ & 5 \\
\hline 6 & & People's attitude towards sport & 1 \\
\hline 7 & & & 3 \\
\hline 8 & & $\begin{array}{l}\text { Providing infrastructure for the } \\
\text { construction and distribution of } \\
\text { private sector }\end{array}$ & 14 \\
\hline 9 & & $\begin{array}{|lll|}\begin{array}{l}\text { Applying } \\
\text { Managers }\end{array} & \text { Powerful Political } \\
\end{array}$ & 3 \\
\hline 10 & & \begin{tabular}{|l|} 
Transparency of law in the \\
implementation of privatization
\end{tabular} & 12 \\
\hline 11 & & $\begin{array}{l}\text { The role of TV in creating sport } \\
\text { culture }\end{array}$ & 4 \\
\hline 12 & & $\begin{array}{l}\text { tax exemption for the private } \\
\text { sector }\end{array}$ & 4 \\
\hline 13 & & $\begin{array}{l}\text { Advertising and appropriate } \\
\text { culture creation for the private } \\
\text { sports sector in press and TV }\end{array}$ & 2 \\
\hline 14 & & $\begin{array}{l}\text { Lack of proper pricing of Private } \\
\text { Clubs' services }\end{array}$ & 1 \\
\hline 15 & & \begin{tabular}{|l|} 
Pessimistic attitude of people \\
toward private sports sectors \\
and problems related to the \\
management and security of \\
private clubs
\end{tabular} & 1 \\
\hline 16 & & $\begin{array}{l}\text { The role of social networks and } \\
\text { media in development of sport }\end{array}$ & 4 \\
\hline
\end{tabular}

\begin{tabular}{|c|c|c|}
\hline 17 & $\begin{array}{l}\text { Changing the attitude of manag- } \\
\text { ers toward privatization }\end{array}$ & 9 \\
\hline 18 & $\begin{array}{l}\text { Not being a priority getting out } \\
\text { of the household basket }\end{array}$ & 4 \\
\hline 19 & $\begin{array}{l}\text { Top-down Attitude of the Gov- } \\
\text { ernment to the Private Sector }\end{array}$ & 4 \\
\hline 20 & $\begin{array}{l}\text { Promoting management culture } \\
\text { in politicians }\end{array}$ & 6 \\
\hline 21 & Guarantee of Foreign Investors & 4 \\
\hline 22 & $\begin{array}{l}\text { Proper and fair pricing of the } \\
\text { private sector }\end{array}$ & 2 \\
\hline 23 & $\begin{array}{l}\text { Government support umbrella in } \\
\text { the privatization of professional } \\
\text { sport }\end{array}$ & 2 \\
\hline 24 & $\begin{array}{l}\text { Eliminating the attitude of reve- } \\
\text { nue generation and more inter- } \\
\text { action with the private sector }\end{array}$ & 4 \\
\hline 25 & $\begin{array}{l}\text { Coordination of private sport } \\
\text { sector plans with the country's } \\
\text { large and strategic plans }\end{array}$ & 2 \\
\hline 26 & $\begin{array}{l}\text { Creation of popular demands for } \\
\text { sports development }\end{array}$ & 2 \\
\hline 27 & Relying on oil resources & 1 \\
\hline 28 & $\begin{array}{l}\text { The existence of a trusted organ- } \\
\text { ization for planning and policy- } \\
\text { making in the private sector }\end{array}$ & 5 \\
\hline 29 & $\begin{array}{l}\text { The attitude of national media } \\
\text { revenue generation rather than a } \\
\text { developmental look in sport }\end{array}$ & 2 \\
\hline 30 & $\begin{array}{l}\text { Influence of the general policies } \\
\text { of the system }\end{array}$ & 4 \\
\hline 31 & $\begin{array}{l}\text { Managers' familiarity with Pri- } \\
\text { vate Management Skills }\end{array}$ & 1 \\
\hline 32 & $\begin{array}{l}\text { The high potential of the country } \\
\text { for planning the structure of the } \\
\text { privatization of sport }\end{array}$ & 1 \\
\hline 33 & $\begin{array}{l}\text { Religious and cultural conditions } \\
\text { for women to enter sport }\end{array}$ & 1 \\
\hline 34 & $\begin{array}{l}\text { Small capacity of the country for } \\
\text { private sector to enter }\end{array}$ & 1 \\
\hline 35 & $\begin{array}{l}\text { development of sports by munic- } \\
\text { ipalities and Ministry of Educa- } \\
\text { tion development }\end{array}$ & 4 \\
\hline 36 & $\begin{array}{l}\text { Free entry and exit permit to } \\
\text { competitive market }\end{array}$ & 1 \\
\hline 37 & $\begin{array}{l}\text { Facilitating permission for as- } \\
\text { signment }\end{array}$ & 1 \\
\hline 38 & $\begin{array}{l}\text { The activities of knowledge } \\
\text { based companies for the training } \\
\text { of human resources }\end{array}$ & 1 \\
\hline 39 & $\begin{array}{l}\text { The availability of a legal base for } \\
\text { transferring to the private sector }\end{array}$ & 1 \\
\hline 40 & $\begin{array}{l}\text { The government should have a } \\
\text { policy maker role not occupying } \\
\text { role }\end{array}$ & 1 \\
\hline 41 & $\begin{array}{l}\text { Ideal expectations without } \\
\text { executive guarantee }\end{array}$ & 1 \\
\hline & Total & 139 \\
\hline
\end{tabular}


By checking the game codes in this group, it became clear that these codes could be attributed to a class above abstraction. Hence, in this structure, the definition of substructures was also discussed. This classification is presented in Table 3.

Table 3 - The results of the second level axial coding (classifying)

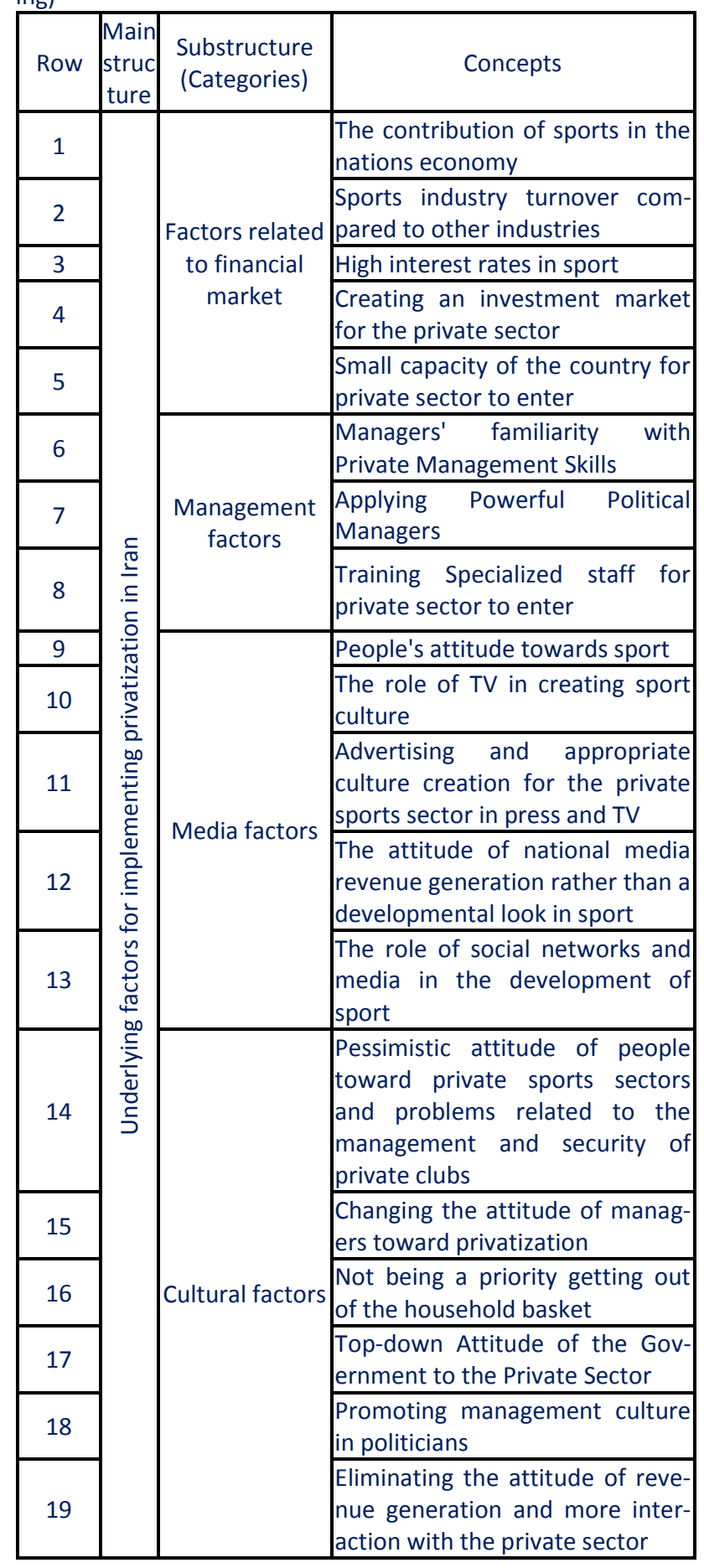

\begin{tabular}{|c|c|c|}
\hline 20 & & $\begin{array}{l}\text { Creation of popular demands for } \\
\text { sports development }\end{array}$ \\
\hline 21 & & $\begin{array}{l}\text { Religious and cultural conditions } \\
\text { for women to enter sport }\end{array}$ \\
\hline 22 & & $\begin{array}{l}\text { development of sports by munic- } \\
\text { ipalities and Ministry of Educa- } \\
\text { tion development }\end{array}$ \\
\hline 23 & \multirow{19}{*}{ Legal factors } & $\begin{array}{l}\text { Government subsidies to enter } \\
\text { the private sector }\end{array}$ \\
\hline 24 & & $\begin{array}{l}\text { Providing infrastructure for the } \\
\text { construction and distribution of } \\
\text { private sector }\end{array}$ \\
\hline 25 & & $\begin{array}{l}\text { Transparency of law in the } \\
\text { implementation of privatization }\end{array}$ \\
\hline 26 & & $\begin{array}{l}\text { Tax exemption for the private } \\
\text { sector }\end{array}$ \\
\hline 27 & & $\begin{array}{l}\text { Lack of proper pricing of Private } \\
\text { Clubs' services }\end{array}$ \\
\hline 28 & & Guarantee of Foreign Investors \\
\hline 29 & & $\begin{array}{l}\text { Proper and fair pricing of the } \\
\text { private sector }\end{array}$ \\
\hline 30 & & $\begin{array}{l}\text { Government support umbrella in } \\
\text { the privatization of professional } \\
\text { sport }\end{array}$ \\
\hline 31 & & $\begin{array}{l}\text { Coordination of private sport } \\
\text { sector plans with the country's } \\
\text { large and strategic plans }\end{array}$ \\
\hline 32 & & $\begin{array}{l}\text { The existence of a trusted orga- } \\
\text { nization for planning and policy- } \\
\text { making in the private sector }\end{array}$ \\
\hline 33 & & $\begin{array}{l}\text { Influence of the general policies } \\
\text { of the system }\end{array}$ \\
\hline 34 & & $\begin{array}{l}\text { Free entry and exit permit to } \\
\text { competitive market }\end{array}$ \\
\hline 35 & & $\begin{array}{l}\text { Facilitating permission for as- } \\
\text { signment }\end{array}$ \\
\hline 36 & & $\begin{array}{l}\text { The availability of a legal base for } \\
\text { transferring to the private sector }\end{array}$ \\
\hline 37 & & $\begin{array}{l}\text { The government should have a } \\
\text { policy maker role not an occupy- } \\
\text { ing role }\end{array}$ \\
\hline 38 & & \begin{tabular}{|lll} 
Ideal expectations without \\
executive guarantee
\end{tabular} \\
\hline 39 & & Relying on oil resources \\
\hline 40 & & $\begin{array}{l}\text { The activities of knowledge } \\
\text { based companies for the training } \\
\text { of human resources }\end{array}$ \\
\hline 41 & & $\begin{array}{l}\text { The high potential of the country } \\
\text { for planning the structure of the } \\
\text { privatization of sport }\end{array}$ \\
\hline
\end{tabular}

As a result of the analysis of the opinions of the participants in the research, five categories were identified: Factors related to financial market, management factors, media factors, cultural factors and legal factors 
that provide the platform for implementation of privatization in the sport of the country.

\section{DISCUSSION AND CONCLUSION}

The results of the research identified 41 concepts and 5 categories including factors related to financial market, management factors, media factors, cultural factors and legal factors that provide the platform for implementation of privatization in the sport of the country. The detailed description of the answer to this question is as follows:

Privatization is considered as the roots of democracy and is a social concept. If society is bigger than the government then it can be stated that privatization can progress. On the other hand, wherever a strong government exists, the private sector will be weakened. Also, due to the large size of the government in the Middle East, there remains little room for individual choice, and there is no sign of freedom of individual action in the Middle East;

As a result, we will have weak societies and strong government. Also, evidence suggests that in countries with oil economy like Iran, economic power is concentrated in the hands of the government, and there is very little space for the presence of economical, political and social activists outside the public system (SARIOLGHALAM, 2006). In countries where the private sector is unhealthy and undeveloped which needs government support, the defined effectiveness is not compatible with its well-known approach; Therefore, although privatization is a policy that has been successful in many developed countries, It should be noted that if the conditions and prerequisites for it are not provided, the decision to privatize leaves no favorable effects on the economy of the country; In Africa, for example, privatization programs encountered a lot of difficulties due to lack of financial infrastructure and private sector disability. Also in countries such as Kenya, Jamaica and Peru, lack of government support and their reliance on foreign support has been one of the reasons for the failure of privatization (IMF, 1996).

Den Hurk et al. (2015), in a study entitled "Public-Private Partnership in Sport Infrastructure: Interference of Complexity in Belgium", stated that the discrepancy between the government complex approach and the relatively simple infrastructures is evident. Therefore, the arguments show that achieving a better understanding of future plans is required. Mohammadi Moghani et al. (2016) in a study entitled "The factor analysis of the state's political role in implementing the privatization policy of the sports industry", found that the effect of political-social cohesion, rule of law and government power on the privatization on the privatization of Iran's sport is significant.

As the results of the data obtained from interview with the elite and similar research revealed, the factors associated with financial market, management factors, media factors, cultural factors and legal factors are factors that provide the platform for implementation of privatization in the sport of the country. Prior to transferring from state ownership to private ownership, its platform should be provided in the country. Prior to implementing privatization in sport, the community should be prepared for this development by specialized and accurate estimates and assessing the condition. These measures include investigating the pri- 
vate sector's financial, managerial and legal ability to privatize sport, improving the executive capacity of the government regarding the regulation of private sector activities in sport and the political consensus of the community about participation of the private sector in its activities and playing a role in society. So far, not enough attention has been paid to privatization. If managers' attitudes toward the presence of the private sector changes and they have a collaborative approach, they will surely provide a more effective context for the private sector. Approving and providing underlying solutions in the field of construction and assignment of facilities and equipment to the private sector can play an effective role in the presence of the private sector in the sport of the country. If the government can provide proper infrastructure and program for the transfer of sports clubs facilities and clubs to the private sector, it will provide a good platform for privatizing the sport. In management, the training of specialist to enter the private sector the use of powerful political managers and the familiarity of managers with managerial skills can strengthen this section and take steps for implementation of privatization in the country.

It is expected that this research has caused sufficient understanding of the factors influencing the sport in Iran. One of the required conditions is management. Sports officials should, as far as possible, provide the conditions for the training of specialist staff to enter the private sector and the familiarity of managers with the private sector managerial skills, and applying workforce educated in Physical education and university professors to the private sector. Also, since one of the underlying conditions is the attraction of the media foreign and domestic investor, the press and the media should promote the private sector of sport and try to introduce the country in order to attract foreign and domestic investors.

Considering that one of the underlying categories in the privatization of sports is cultural-social factors, it is recommended that the authorities, taking into account the philosophy of sport and culture among the people, as well as the developmental role of sports by complementary institutions such as municipalities and ministry of Education, provide the context for private sector to participate in all sectors of development of the country's sport.

\section{REFERENCES}

AMANI, A. et al. The management problems of privatized athletic facilities in northern Khorasan and Razavi Khorasan province. Research in Sport Management and Psychology, Vol. 2, Issue 4: 1-6, 2014.

ANIBAL INSFRAN PELOZO, J. "Privatization in Paraguay: some lessons," The Quarterly Review of Economics and Finance, Elsevier, vol. 41(5): 737-753, 2001. https://doi.org/ 10.1016/S1062-9769(01)00101-6

AYIM, E. M. A thesis, University of Nevada, (Las Vegas, USA), 2009.

AYUBI, N. A comparative perspective on privatization programmes in the Arab World, In Younis T., Privatization: A review of policy and implementation in selected Arab countries, International Journal of public sector management, Vol.9, No.3, pp.18-25, 1995; 1996. https://doi.org/10.11 08/09513559610124450

CHOWDHURY, F.L. Corrupt Bureaucracy and privatization of tax enforcement, pathaksamabesh, Dhaka, 2006. 
CLARK, J. M.; CORNWELL, B. P.; STEPHEN, $W$. The impact of title event. Sponsorship announcements on shareholder wealth, market let, 2008. https:// doi.org/10/1007/ s11002-008-9004.

DEN HURK, M.; VERHOEST, K. The governan ce of public-private partnerships in sports infrastructure: Interfering complexities in Belgium. International Journal of Project Management, Volume 33, Issue 1, January 2015, Pages 201-211, 2015.

GRUSKY, S.; FIIL-FLYNN, M. Will the World Bank Back down? Water Privatisation in a Climate of Global Protest (Washington, D.C: Public Citizen); P: 18-19, 2004.

HOOMAN, H. Understanding the Scientific Method in Behavioral Sciences. Tehran; Samt publication, 2007.

IMF. Annual Report of the Executive Board for the Financial Year Ended April 30. IMF Publications, Washington, D.C., 1996.

KARLIS, G. The future of leisure, recreation and sport in Canada: a SWOT for small sized enterprises. The Sport Journal, 9 (2), 7, 2006.

MIAO CHANG; HIDEFUMI IMURA. Developing Private Finance Initiatives (PFI) PublicPrivate Partnership (PPP) for Urban Environmental Infrastructure in Asia, 2008. Retrived from: http://lenviroscope.iges.or. $\mathrm{jp} /$ modules/envirolib/upload/23/attach/ue 2-3009.pdf.2008/08/23.

MOHAMMADI MOGHANI, H. ET AL. The factor analysis of the government political role in implementing the privatization policy in sports industry, New Approaches to Sport Management. 4 (13): 61-72, 2016.

MUNARI et al. "Privatization process and the redefinition of corporate R\&D boundaries". Journal of Research Policy, Vol.31, p. 31-53, 2002. https://doi.org/10.1016/S004 8-7333(01)00108-1

Estação Científica (UNIFAP)

ISSN 2179-1902
SARIOLGHALAM, M. Democracy in the Middle East: Limitations and Prospects, the Bruno Kreisky Forum for International Dialogue, 2006.

SGL CONSULTING GROUP. State Level Sporting Facilities Strategic Plan 2001-2017, 2006. Retrieved from: http//www.Recsport. sa.gov.au/pdf/draft-final-report-2007-2017. pdf.

SMITH, S. J. "Football, Its Values, Finances and Reputation". Informe para la Football Association, 1997.

THANOS; KRIEMADIS. Strategic marketing planning in the sport sector. Sport Management International Journal 3, 1, 33-35, 2007.

WU XIAO, R.; HU, X. Consideration of Privatisation Management of public sport facilities. Journal Hubei sports science 26. 1011, 2007.

ZOLFAGHARIYAN, M. et al. Data based Theorization by Vivo Software, Publication of Imam Sadiq University (AS), Tehran, 2011.

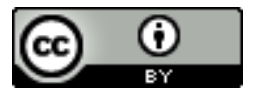
access article distributed under the terms of the Creative Commons Attribution License, which permits unrestricted use, distribution, and reproduction in any medium, provided the original work is properly cited.

Article received on February 12, 2018.

Evaluated March 02, 2018.

Accepted on March 19, 2018.

Published on May 25, 2018.

How cite this article (ABNT):

RAZAVI, Seyed Mohammad Hossein; AMANI, Amin; FIROUZABADI, Alireza Ghanbari. An analysis of underlying factors for implementing privatization in Iranian Sport. Estação Científica (UNIFAP), Macapá, v. 8, n. 1, p. 57-65, jan./abr. 2018. 